\title{
OBIEKTY ŻYCIA KULTURALNEGO W CIECHOCINKU W XIX WIEKU. TEATR
}

$\mathrm{R}$ ozwój balneologii i nowy styl życia, związany z troską o własne zdrowie, były przyczyną powstania i rozbudowy ośrodków uzdrowiskowych na terenie całej dziewiętnastowiecznej Europy. Wakacyjne wyjazdy do zdrojów stały się w tym okresie bardzo popularne. Wiązały się z prestiżem i świadczyły o przynależności do towarzystwa ${ }^{1}$. Ośrodki, chcąc przyciągnąć do siebie i ugościć możliwie jak największą liczbę kuracjuszy, szczególnie tych bogatych, zobowiązane były stopniowo rozszerzać swoją ofertę, nie tylko leczniczą, ale i rozrywkową. Największe europejskie zdrojowiska gościły w drugiej połowie XIX w. w sezonie nawet 30 tysięcy kuracjuszy ${ }^{2}$. Przyjezdnym należało zapewnić zakwaterowanie, wyżywienie, opiekę medyczną oraz zróżnicowane zabiegi lecznicze. Jednocześnie dbano o zorganizowanie gościom rozrywki, tak, aby wypełnić i uprzyjemnić spędzony w uzdrowisku wolny czas. Rozwinięcie oferty kulturalno-rozrywkowej było dla zdrojów tym bardziej istotne, że - jak pokazują dzisiejsze badania, wśród zjeżdżających do uzdrowisk gości tylko około $30 \%$ udawało się tam w celu ratowania zdrowia ${ }^{3}$. Pozostałą część stanowiła nie tylko służba, ale i rodzina oraz znajomi, z którymi wspólnie podróżowano, a których głównym celem pobytu była zabawa i wypoczynek. Rozwój renomowanych kurortów zachodnich postępował bardzo szybko, a zdrojowe obiekty świadczące usługi wznoszono na ogromną skalę. Obok monumentalnych kompleksów przyrodoleczniczych, okazałych pijalni wód i galerii spacerowych, budowano tu domy zdrojowe, teatry, czy też muszle koncertowe.

\footnotetext{
${ }^{1}$ M. Matysiak, „Ci tańcza, ci się patrza, a wszyscy weseli. Nawet chorzy na chwile chorób zapomnieli" - życie towarzyskie i rozrywki w XIX-wiecznych uzdrowiskach (1795-1863), [w:] Kultura uzdrowiskowa na Dolnym Śląsku w kontekście europejskim, t. 1, pod. red. B. Płonki-Syroki i A. Kazimierczak, Wrocław 2013, s. 229-230.

${ }^{2}$ M. Zieleniewski, Nasze zaklady zdrojowo-kapielowe i hydropatyczne tudzież uzdrowiska klimatyczno-lecznicze, [w:] Józefa Czecha Kalendarz Krakowski na rok 1894, Kraków 1894, s. 79.

${ }^{3}$ B. Płonka-Syroka, Uwarunkowania medyczne i społeczne ksztattowania się standardu kultury uzdrowiskowej w Europie czasów nowożytnych - rys historyczny, [w:] Kultura uzdrowiskowa na Dolnym Śląsku w kontekście europejskim, t. 1 ..., s. 47.
} 
Uzdrowiska powstawały także na ziemiach dawnej Rzeczypospolitej. W pewien sposób integrowały one polską społeczność pozbawioną wówczas własnego, suwerennego państwa ${ }^{4}$. Jednak pozyskanie środków finansowych na ich utrzymanie i rozbudowę było mocno utrudnione, władzom państw zaborczych nie zależało bowiem na rozwoju polskiej gospodarki. Problem tkwił także w samych kuracjuszach, którzy kierując się prestiżem miejsca i spotkaniami towarzyskimi wyższych sfer, chętniej wybierali wyjazd do zagranicznych „badów”, oferujących im większy komfort pobytu i jakość usług 5 . Tworzyła się zatem sytuacja bez wyjścia, gdyż mniejszy popyt i brak dochodów ze sprzedaży usług uniemożliwiał inwestycje i rozbudowę zdroju, co z kolei miało swoje przełożenie w proponowanej przez nie ofercie ${ }^{6}$. W rezultacie uzdrowiska polskie rozwijały się znacznie wolniej i na zdecydowanie mniejszą skalę, niż renomowane kurorty Europy zachodniej, a na przeprowadzenie inwestycji trzeba było czekać często wiele lat, modyfikując jednocześnie pierwotne założenia i upraszczając projekty. Wiele planów nie zostało też nigdy zrealizowanych.

Podobna sytuacja miała miejsce również w Ciechocinku, w którym dodatkowe utrudnienie powodował aspekt administracyjny. Funkcjonowały tu bowiem dwa zakłady: warzelniany oraz zdrojowy. Pierwszy działał od lat dwudziestych XIX stulecia i podlegał pod zarząd Banku Polskiego. Zadaniem warzelni stanowiącej ważny punkt na przemysłowej mapie Królestwa Polskiego było pozyskiwanie soli z wydobywanej z głębin solanki. Zakład zdrojowy zaczął się rozwijać po tym, jak odkryto także inne - lecznicze właściwości miejscowej wody. Choć pierwsi kuracjusze zaczęli zjeżdżać tu już od połowy lat trzydziestych ${ }^{7}$, to rzeczywisty rozwój uzdrowiska nastąpił dopiero od roku 1843. Powołano wówczas Komitet do Obmyślania Środków Wzniesienia Zakładu Wód Mineralnych w Ciechocinku, urzędujący w gmachu Komisji Rządowej Spraw Wewnętrznych i Duchownych w Warszawie ${ }^{9}$, oraz działający na miejscu Zarząd. Aby jednak możliwe było rozwijanie się zakładu zdrojowego, istniała konieczność wcześniejszego uzyskania na ten cel gruntów od zakładu warzelnianego. Rozbudowane procedury administracyjne wydłużały czas realizacji niektórych inwestycji i ograniczały szybki rozwój ośrodka ${ }^{10}$. Mimo utrudnień, dzięki pracy i zaangażowaniu członków Zarządu Wód Mineralnych, w Ciechocinku stopniowo i na miarę możliwości

\footnotetext{
${ }^{4}$ M. Matysiak, dz. cyt., s. 229.

${ }^{5}$ Por. J.T. Tchórznicki, Nasze Zdrojowiska (Ciechocinek, Busko, Nałęczów, Stawuta), „Kraj” 1893, nr 27, s. 3-6.

${ }^{6}$ B. Płonka-Syroka, dz. cyt., s. 51.

${ }^{7}$ Za początek istnienia uzdrowiska uznaje się rok 1836, kiedy w miejscowej oberży urządzone zostały pierwsze łazienki.

${ }^{8}$ Nazywany Komitetem Głównym, w odróżnieniu od Miejscowego Komitetu (budowy łazienek).

${ }^{9}$ M. Raczyński, Materjały do historii Ciechocinka. Od zapoczątkowana budowy warzelniów soli do wybuchu wielkiej wojny, Warszawa 1935, s. 208-209.

${ }^{10}$ Tak było w przypadku stopniowego rozszerzania zdrojowego parku.
} 
rozbudowywano infrastrukturę i organizację uzdrowiska. Podobnie, jak w innych ośrodkach, także w Ciechocinku poza możliwością skorzystania $\mathrm{z}$ różnorodnych zabiegów leczniczych, można było m.in. odpoczywać spacerując w parku przy dźwiękach muzyki, bawić się na balach, uczestniczyć w koncertach, czy śmiać się na wystawianych w teatrze komediach. Wśród obiektów o charakterze kulturalno-towarzyskim, które wzniesione zostały z inicjatywy miejscowego Zarządu w XIX w., wymienić należy: teatr, galerię spacerową (późniejszy tzw. kurhaus) ${ }^{11}$ oraz powstałe w pobliżu galerii i tężni estrady muzyczne. Wspomnianą rolę spełniał także miejscowy hotel Müllera, który poza zakwaterowaniem i wyżywieniem, oferował gościom cykliczne zabawy taneczne oraz różnorodne koncerty i pokazy. Najważniejszymi, z punktu widzenia kultury obiektami, w których realizowano program artystyczny, były teatry. Dlatego niniejszy artykuł koncentruje się właśnie na nich. Zarówno tych powstałych, jak również tych, które zapisały się na kartach historii jako niezrealizowane marzenia Ciechocinka. Omówienie kolejnych scen teatralnych uzdrowiska ma na celu pokazanie, jaka była ich skala i z jakimi trudnościami zmagano się podczas ich realizacji.

W Ciechocinku pierwsze obiekty teatralne miały formę bardzo prowizoryczną. Urządzane w szopach czy magazynach, składały się ze skromnej sceny połączonej $\mathrm{z}$ widownią, która $\mathrm{w}$ zależności od potrzeb wykorzystywana była również jako sala taneczna, czy koncertowa. Przyczyna tkwiła także w samym położeniu uzdrowiska. Ziemia, na jakiej powstawał Ciechocinek, stanowiła bowiem naturalny obszar zalewowy. Coroczne powodzie powodowały tak ogromne szkody, że nawet gdyby pozwoliły na to fundusze (bez wcześniejszego zabezpieczenia uzdrowiska), nie opłacało się inwestować w bardziej okazałe obiekty ${ }^{12}$.

Ciechocinek $\mathrm{w}$ pierwszych latach swojego istnienia przypominał raczej skromną osadę, gdzie oprócz warzelnianych obiektów istniało tylko kilkanaście domów i oberża. Resztę terenu stanowiły piaski, okoliczne pola i sosnowe lasy. W tym otoczeniu powstał pierwszy prowizoryczny teatr, do którego urządzenia skłoniły narzekania na brak rozrywek pierwszych przybywających do uzdrowiska kuracjuszy ${ }^{13}$. Powstał on około 1839 r. w szopie przy tzw. Białych Domach - miejscach zamieszkania pracowników warzelni soli. Jego inicjatorem był

${ }^{11}$ Choć sam obiekt galerii spacerowej należałoby raczej zaliczyć do budynków pełniących w uzdrowisku funkcję leczniczą (chroniła ona bowiem spacerujących kuracjuszy przed niekorzystnymi warunkami pogodowymi), to pod jej dachem koncentrowało się w znacznym stopniu życie towarzyskie uzdrowiska. Jej nieodłącznym elementem były powstałe w jej pobliżu estrady muzyczne, gdzie po kilka godzin dziennie grała orkiestra, uprzyjemniająca gościom uzdrowiska codzienne spacery przy źródłach. Ponadto druga w kolejności istniejąca galeria - ze względu na urządzoną w niej salę balowo-koncertową oraz czytelnię - uznawana była za uzdrowiskowy kurhaus., zob. G. Balińska, Uzdrowiska dolnoślaskie. Problemy rozwoju i ochrony wartości kulturowych do II wojny światowej, Wrocław 1991, passim.

${ }^{12}$ Sytuacja ta uległa zmianie dopiero na początku lat siedemdziesiątych, kiedy wybudowany w $1871 \mathrm{r}$. wał przeciwpowodziowy zabezpieczył uzdrowisko przed cyklicznymi powodziami.

${ }^{13}$ M. Raczyński, dz. cyt., s. 360. 
zarząd wymienionego przedsiębiorstwa. Dopiero z czasem teatr przeszedł pod opiekę zarządu zdrojowiska. Urządzono go przy uczęszczanej wówczas drodze łączącej Stary Ciechocinek, gdzie kwaterowali się zamożniejsi goście uzdrowi-

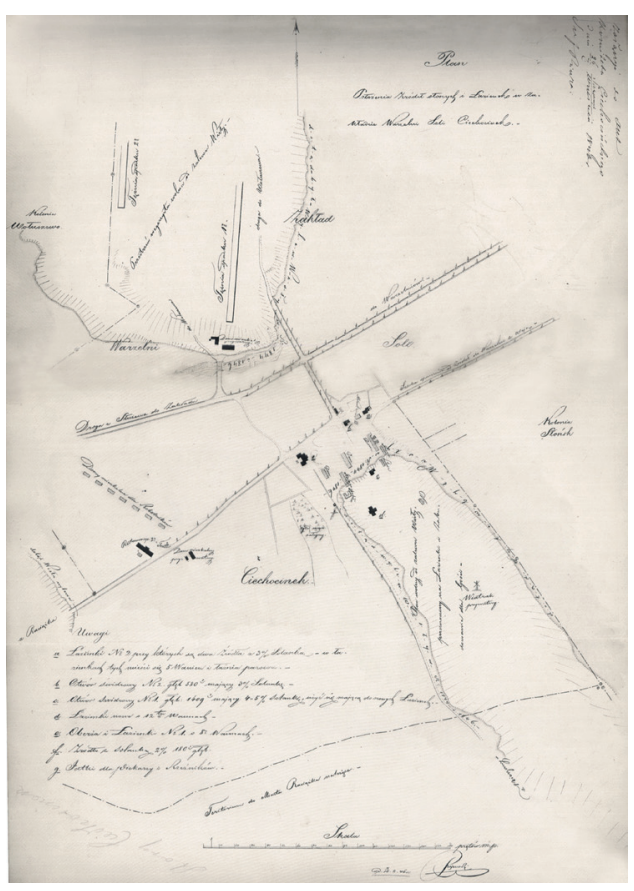

Ryc. 1. Plan Położenia źródet słonych $i$ Łazienek w Zakładzie Warzelni Soli Ciechocinek, 1846.; AP Toruń (d. Włocławek), KZZZWM, sygn. 5, k. 46 ska, a łazienkami, do których udawano się na kurację. Dodatkowy ruch w tej części zdroju powodowała również znajdująca się nieopodal poczta ${ }^{14}$. Dokładną lokalizację pokazuje „Plan Położenia źródeł słonych i Łazienek w Zakładzie Warzelni Soli Ciechocinek" z 1846 r. (ryc. 1). Teatr urządzono w osobnym budynku, który wcześniej pełnił funkcję magazynu ${ }^{15}$. W oddzielnych pomieszczeniach mieściły się tam również: restauracja i cukiernia ${ }^{16}$. Zarząd warzelni udostępniał salę bezpłatnie. Z kolei o utrzymanie $\mathrm{w}$ niej porządku, oświetlenia i zapewnienia oprawy muzycznej na wieczór dbał za opłatą dzierżawca restauracji i cukierni. W jego interesie było czuwanie nad jakością organizowanych tu wydarzeń teatralnych i tanecznych, gdyż zwiększały one obroty w prowadzonej przez niego działalności ${ }^{17}$.

Teatr mieścił prowizoryczną scenę i dwa pomieszczenia garderobiane. Początkowo brakowało w nim typowej widowni, a oglądająca widowiska publiczność zmuszona była śledzić przedstawienie siedząc na wystawianych w ogrodzie ławkach ${ }^{18}$. Widownię ${ }^{19}$ dobudowano dopiero w 1846 r., czego podjął się ówczesny dzierżawca restauracji - Karol Müller $^{20}$. Korespondent „Dziennika Warszawskiego” w roku 1854 w następujący sposób opisuje miejscowy teatr:

${ }^{14}$ O. Flatt, Brzegi Wisty od Warszawy do Ciechocinka, Warszawa 1854, s. 98; R. Ignatowski, O wodach słonych w Ciechocinku, jéj działaniu i zastosowaniu lekarskiém, Warszawa 1854, s. 12.

${ }^{15}$ M. Raczyński, dz. cyt., 360; Archiwum Państwowe w Toruniu /d. Włocławek/, Zespół akt Komitetu Zarządzającego Zakładem Wód Mineralnych w Ciechocinku 1. (1823) 1842-1914 (dalej: APW, KZZWM), sygn. 1, k. 128.

${ }^{16}$ M. Raczyński, $d z$. cyt., s. 363.

${ }^{17}$ Tamże, s. 360, 363.

${ }^{18}$ Tamże, s. 360.

${ }^{19}$ Wymiary widowni: 31 x 25 x 7,5 stopy (ok. 9,45 x 7,62 x 2,29 m), [za:] M. Raczyński, dz. cyt., s. 363.

${ }^{20}$ Koszt remontu wyniósł 57,69 rubli, M. Raczyński, dz. cyt., s. 363. 
Zabudowanie, w którem się odbywają przedstawienia jest drewniane mogące pomieścić 200 z górą osób, aczkolwiek szczupłe i niskie, ma przynajmniej zaletę porządku i czystości. Kiedyś ferentis auspitis, powstać tu ma teatr ozdobny i wygodny, zanim to jednak nastąpi trzeba się cieszyć i tym, który dziś istnieje ${ }^{21}$.

Teatr posiadał dość skromne dekoracje, jak dalej relacjonował korespondent:

na kurtynie Apollo otoczony Muzami szybuje na wozie w powietrzu, a u stóp jego w pośród mórz przestrzeni, widnieje $\mathrm{z}$ dala gród jakiś starodawny; to pewno Ateny - siedlisko sztuk nauk ${ }^{22}$.

Latem występowali tu artyści prowincjonalni, zatrudniani i opłacani przez zarząd uzdrowiska, z którymi każdorazowo podpisywano umowę na okres trwania sezonu. Przestawienia odbywały się w niedziele i czwartki ${ }^{23}$. Dbano, aby repertuar możliwie najlepiej dopasować do upodobań odpoczywających w uzdrowisku gości - wystawiano lżejsze rodzaje $\operatorname{sztuk}^{24}$. Starano się także odgrywać sztuki tych samych autorów, co w teatrach warszawskich ${ }^{25}$. Zapewne wynikało to z chęci przypodobania się publiczności, która przyjeżdżała do zdroju zazwyczaj z dużych miast (głównie Warszawy) ${ }^{26}$. Niemniej ceniono również wystawianie sztuk rodzimych ${ }^{27}$.

Przybył tu i dał już dwa przedstawienia, teatr pod dyrekcją Pana Gaweckiego; dzisiaj Komedja A. Wieniarskiego: Warszawiacy i Hreczkosieje; radzilibyśmy teatrowi czynić i nadal wybór taki, aby zawsze przedstawiano co rodzinne nasze, co przynajmniej swojskie, wesołe, lekkie, a więc łatwe i ponętne ${ }^{28}$ - pisano.

${ }^{21}$ A.D., Korespondencja z Ciechocinka, „Dziennik Warszawski” 1854, nr 203, s. 4.

${ }^{22}$ Tamże, s. 5.

${ }^{23}$ A.D., Korespondencja z Ciechocinka, „Dziennik Warszawski” 1854, nr 194, s. 4.

${ }^{24} \mathrm{~W}$ teatrach uzdrowiskowych wystawiano głównie komedie i operetki. Wynikało to $\mathrm{z}$ faktu, iż pobyt w uzdrowisku miał mieć pozytywny wpływ nie tylko na stan fizyczny kuracjusza, ale i psychiczny. Wszelki wysiłek umysłowy nie był wskazany. Chorym nie zalecano również czytania romansów, kryminałów czy sensacyjnej literatury, aby nie dostarczać sobie niepotrzebnych negatywnych i silnych emocji, E. Mazur, Życie codzienne w uzdrowiskach $w$ Królestwie Polskim i zachodnich guberniach Cesarstwa Rosyjskiego, „Kwartalnik Historii Kultury Materialnej” 2008, R. 56, s. 182.

${ }^{25}$ Przykładowo, w 1854 r. wystawiano w Ciechocinku sztuki Korzeniowskiego, A.D., Korespondencja z Ciechocinka, „Dziennik Warszawski” 1854, nr 225, s. 4.

${ }^{26} \mathrm{~W} 1851$ r. na 477 gości, odwiedzających uzdrowisko - 406 pochodziło z obszaru Królestwa Polskiego (w tym 96 z samej Warszawy), APW, KZZWM, Sprawozdanie z czynności Zarządu Wód Mineralnych w Ciechocinku za 1851, sygn. 10, k. 9.

${ }^{27}$ Teatr na terenach zaborów pełnił również funkcję narodową, podtrzymywał polską tożsamość. W wyniku postępującej rusyfikacji, zaostrzonej szczególnie po upadku powstania styczniowego, stopniowo wprowadzano język rosyjski do kolejnych sfer życia publicznego, m.in. sądownictwa i urzędów (od początku lat siedemdziesiątych także raporty i sprawozdania ciechocińskiego Zarządu sporządzane były w języku zaborcy oraz prowadzono w tym języku korespondencję). Jedynymi instytucjami tolerowanymi przez rząd rosyjski, w których nadal było można swobodnie posługiwać się językiem polskim były: kościół oraz teatr. Dzieje teatru polskiego, pod red. T. Silverta, t. III, Teatr polski od 1863 roku do schytku XIX wieku, Warszawa 1982, s. 22, 234.

${ }^{28}$ „Kurier Warszawski” 1857, nr 176, s. 959. 


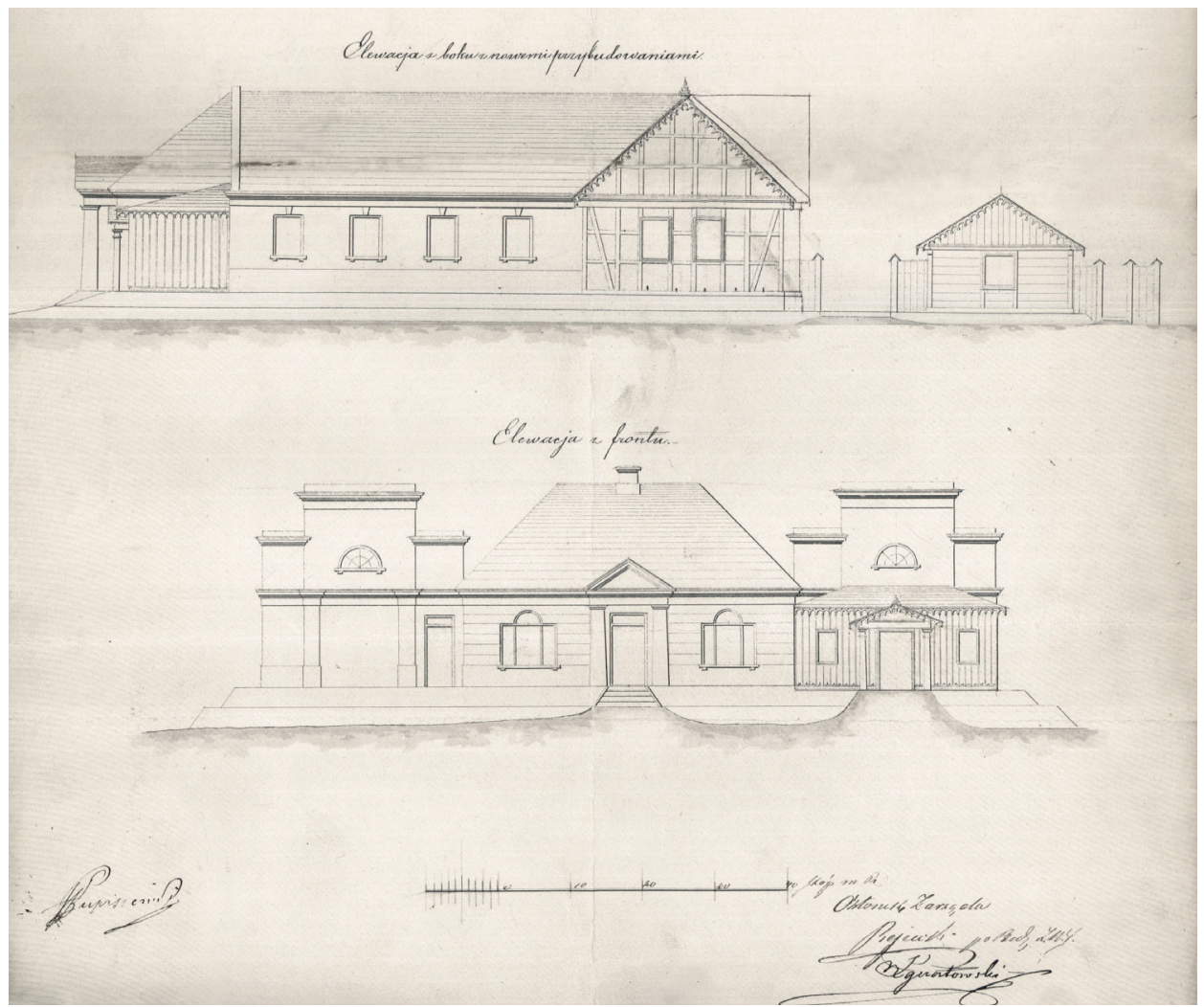

Ryc. 2. Rysunek Oberży w Ciechocinku ze względu na urzadzenie Sali z scena teatralna, Elewacja z frontu, Elewacja z boku z nowemi przybudowaniami, 1857 r.; AP Toruń (d. Włocławek), KZZWM, sygn. 14, k. 251

Dla urozmaicenia przedstawień w czasie przerw pomiędzy kolejnymi aktami grała orkiestra ${ }^{29}$ lub odbywały się pokazy baletowe ${ }^{30}$. W teatrze w Białych Domach, poza sztukami teatralnymi, organizowano koncerty i wieczory taneczne - ,po zasłonięciu kurtyny goście tańczą do dnia białego [...] z czego częstokroć najszkodliwsze skutki wynikają"31.

${ }^{29}$ A.D., Korespondencja ..., „Dziennik Warszawski” 1854, nr 203, s. 5.; W teatrze grała orkiestra, ta sama, która była wynajęta na okres sezonu przez uzdrowiskowy zarząd. Do jej obowiązków należało grać w godzinach porannych przy źródłach, po południu pod tężniami, zaś w dniach kiedy odbywały się przedstawienia, była do dyspozycji teatru, za co otrzymywała odrębne wynagrodzenie - por. APW, KZZWM, sygn. 17, k. 108-109.

${ }^{30} \mathrm{~W} 1847$ r. grał teatr Gaweckiego, który ,przedstawia małe sztuczki w umyślnie na to wystawionej szopie, zwanej Teatrem, ale co jest nowością dla Ciechocinka, to-to, że w antraktach bywają wykonywane tańce baletowe przez Pannę Seredyńskę, i użeśmy widzieli „Szał” i „Kaczeuczę”, „Kurier Warszawski" 1847, nr 189, s. 911.

${ }^{31}$ APW, KZZWM, sygn. 1, k,128. 
Niewątpliwie to właśnie tu, poza łazienkami, skupiało się całe życie kulturalne i towarzyskie w pierwszych latach funkcjonowania ośrodka.

W miarę upływu czasu i użytkowania stan techniczny obiektu ulegał pogorszeniu $^{32}$. Nie chcąc narażać się na niezadowolenie gości zaczęto myśleć o urządzeniu nowej sali widowiskowej. Pierwsze pomysły pojawiły się już w 1847 r., kiedy niejaki Edward Mohr wystąpił z inicjatywą wzniesienia w uzdrowisku nowej oberży, przy której miałby zostać urządzony teatr ${ }^{33}$. Niestety śmierć Mohra udaremniła owe plany ${ }^{34}$. Do podjęcia kolejnych działań zmusiła miejscowy zarząd panująca w 1852 r. epidemia cholery, podczas której warzelniany teatr został czasowo zamieniony na szpital. Powstała wówczas duża wątpliwość, czy w kolejnych latach będzie on w ogóle uczęszczany przez widzów ${ }^{35}$. Zrodził się zatem pomysł przeniesienia teatru do stajni przy miejscowej oberży, co zresztą w owych czasach było bardzo popularne ${ }^{36}$. Nowa lokalizacja była w samym, nowo kształtującym się, centrum uzdrowiska - nieopodal łazienek, galerii spacerowej i Hotelu Müllera. Konieczna była jednak gruntowna przebudowa istniejącego obiektu ${ }^{37}$, czemu na przeszkodzie stanął brak środków finansowych. Plany zdecydowano się odłożyć „na później”38. Przedstawienia dramatyczne, z powodu braku innego pomieszczenia, dalej odbywały się w ,warzelnianej szopie". Do pomysłu ponownie powrócono w 1857 r., sporządzając szczegółowy projekt z kosztorysem, obejmującym urządzenie sali teatralnej wraz z kapitalnym remontem całej oberży ${ }^{39}$.

${ }^{32}$ W 1852 r. miejscowy budynek teatru określany była jako: „stara zniszczona szopa”, APW, KZZWM sygn. 10, k. 113-114.

${ }^{33}$ APW, KZZWM, sygn. 6, k. 108-112, 191.

${ }^{34} \mathrm{Na}$ terenie, o który ubiegał się Mohr, kilka lat później wzniesiono Hotel Müllera.

${ }^{35}$ APW, KZZWM, Sprawozdanie z czynności Zarządu Wód Mineralnych w Ciechocinku za rok 1852, sygn. 10, k. 152-153.

${ }^{36}$ Znanych jest wiele przykładów urządzenia scen teatralnych we wnętrzach murowanych lub drewnianych stajni miejscowego zajazdu, m. in. w Białej Podlaskiej, Hrubieszowie, Koninie, Krasnymstawie, Łęcznej, Łowiczu, Łukowie, Siedlcach, zob. W. Tomaszewski, Miedzy salonem a jarmarkiem, Warszawa 2012, s. 132.

${ }^{37}$ „Ciechocinek nie ma teatrzyku i przedstawienia odbywają się tylko w starej zniszczonej szopie przy oberży w długoletnią dzierżawę zakładowi kąpielowemu oddanej, jest stajnia i dosyć obszerna i wysoka - lecz bardzo niedogodna z powodu wysokiego i przykrego wjazdu oraz bliskiego sąsiedztwa z restauracyją. Nadto sama budowla potrzebuje gruntownej reparacji bez której upadłaby wkrótce. Zamiast restaurować niedogodną stajnię. Zarząd proponuje urządzić ją na teatrzyk, co przyozdobi to miejsce, a w tyle oberży wybudować stajnię drewnianą z dwiema izbami na szynk, który tym sposobem usunie się z bliskiego sąsiedztwa Łazienek Nr II i restauracyji - fundusz na to potrzebny byłby w sumie koło rubli 1200", APW, KZZWM sygn. 10, 113-114.

${ }^{38}$ Tamże, sygn. 13, k. 42-43, 168.

${ }^{39}$ Tamże, sygn. 14, k. 209. 


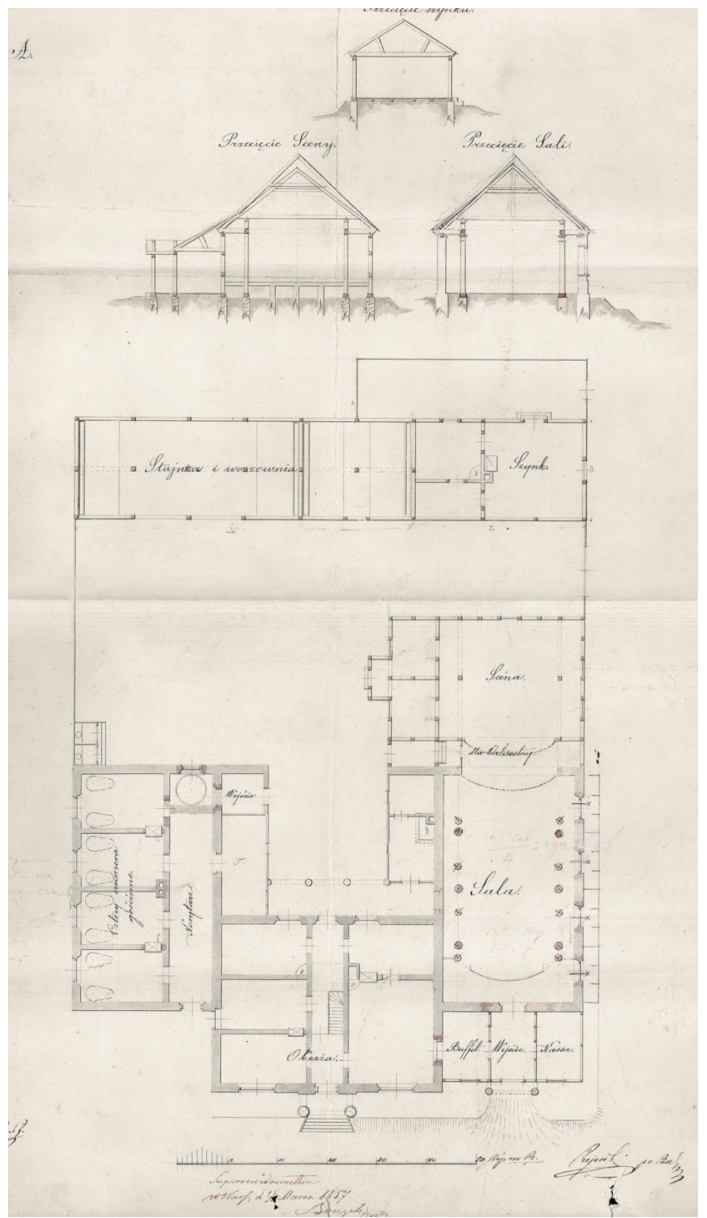

Ryc. 3. Rysunek Oberży w Ciechocinku ze względu na urzadzenie Sali z scena teatralna, rzut i przekroje: sali, sceny $i$ szynku, 1857 r.; AP Torun (d. Włocławek), KZZWM, sygn. 14, k. 251
Przedstawiał się on w sposób następujący: dotychczasowa drewniana stajnia ${ }^{40}$ miała zostać przerobiona na widownię. Planowano dobudowanie murowanej sceny $^{41}$ wraz z dwoma pomieszczeniami garderobianymi oraz pomieszczeniem dla orkiestry, zaopatrzonym w oddzielne boczne wejście. Od frontu miała powstać drewniana dobudów$\mathrm{ka}^{42}$ mieszcząca główne wejście wraz $\mathrm{z}$ kasą i małym bufetem ${ }^{43}$ (ryc. 2, 3). Projekt skonsultowano nawet $\mathrm{z}$ architektem Henrykiem Marconim. Niestety, jak poprzednio, także i tym razem, niewystarczająca ilość środków finansowych stanęła na przeszkodzie rychłej realizacji planu ${ }^{44}$. Wciąż były inne ,ważniejsze” potrzeby w uzdrowisku, które pochłaniały większą cześć jego budżetu ${ }^{45}$. Ponadto, jak wynika z rocznego sprawozdania Zarządu Uzdrowiska w 1861 r., skrzydło oberży, w której planowano pomieścić teatr, zostało oddane na użytek przebywającego wówczas w Ciechocinku wojska ${ }^{46}$.

${ }^{40}$ Wymiary stajni: 49 x 30 stóp, wys. 12 stóp (ok. 15 x 9, wys. 3,5 m), APW, KZZWM, sygn. 14, k. 207-233.

${ }^{41}$ Planowano jej wybudowanie na kamiennym fundamencie, ściany z muru pruskiego, dach kryty dachówką; wymiary: 30 x 39 stopy (ok. 9 x 12 m), APW, KZZWM, sygn. 14, k. 207-233.

${ }^{42}$ Wymiary dobudówki: 28 x 14 stopy, wys. 8 stóp (ok. 8,5 x 4, wys. 2,5 m), APW, KZZWM, sygn. 14 k. 207-233.

${ }^{43}$ APW, KZZWM, sygn. 14, k. 207-233, 251.

${ }^{44}$ M. Raczyński, $d z$. cyt., s. 230.

${ }^{45}$ M. in. modernizacja łazienek, urządzenie ścieżek i chodników, rozszerzenie zdrojowego parku. Dużą część pieniędzy pochłaniały również bieżące naprawy związane ze zniszczeniami jakie wyrządzały coroczne wylewy Wisły.

${ }^{46}$ APW, KZZWM, sygn. 16, k. 32. 
Nową salę teatralną urządzono w zaplanowanym miejscu dopiero blisko dekadę później - w $1867 \mathrm{r}^{47}$ (ryc. 4). Niewątpliwie zmobilizował do tego również większy napływ gości do uzdrowiska, którym należało stworzyć bardziej komfortowe miejsce dla rozryw$\mathrm{ki}^{48}$. Z drugiej strony urządzenie teatru w miejscowej stajni łączyło się też z możliwościami finansowymi zakładu, gdyż generowało niewątpliwie mniejsze koszty, ani-

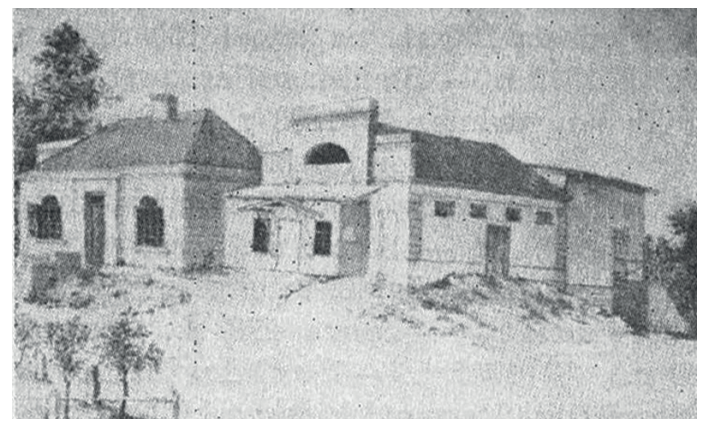

Ryc. 4. Teatr przy oberży przerobiony ze stajni, M. Raczyński, Materjaty do historii Ciechocinka. Od zapoczatkowana budowy warzelniów soli do wybuchu wielkiej wojny, Warszawa 1935, s. 361

żeli budowa kompleksowo wyposażonego kurhausu - z restauracją, kawiarnią, czytelnią, salą na spotkania towarzyskie i teatrem - o budowie którego wciąż mówiono, a którego brak coraz bardziej dawał się odczuć w uzdrowisku ${ }^{49}$.

Wejście nowego teatru znajdowało się od strony restauracji. Wewnątrz ułożono podłogę i zamontowano prowizoryczny pułap ${ }^{50}$. Aby obniżyć jednak koszt budowy, zdecydowano się na pobudowanie $\mathrm{z}$ drewna nie tylko frontowej przybudówki, ale i sceny z drewna ${ }^{51}$. Całkowity koszt budowy wyniósł jedynie 750 rubli i został opłacony przez ówczesnego naczelnika ciechocińskich salin, który w zamian za każde wystawione przedstawienie otrzymywał od zarządu wynagrodzenie ${ }^{52}$. W 1875 r. został przeprowadzony częściowy remont teatru. Modernizacja obejmowała powiększenie dotychczasowych pokojów garderobianych, jak również urządzenie dwóch dodatkowych ${ }^{53}$. Rok później wyremontowano także pozostałą część pomieszczeń ${ }^{54}$. Powrócono również do nieodpłatnego udostępniania sali ${ }^{55}$ - nie jest wykluczone, że było to związane z poprawą

\footnotetext{
${ }^{47}$ E.L. [E. Lubowski], Korespondencya z Ciechocinka, ,Tygodnik Ilustrowany” 1867, nr 410, s. 57.

${ }^{48} \mathrm{~W} 1867 \mathrm{r}$. został otwarta linia kolejowa łącząca Ciechocinek z pobliskim Aleksandrowem Kujawskiem (leżącym na ważnym szlaku kolejowym - linii warszawsko-bydgoskiej). Poprawiło to znacząco komunikację z uzdrowiskiem. Ponadto zaostrzone zostały również restrykcje władz rosyjskich po powstaniu styczniowym - obejmujące m. in. utrudnienie wydawania paszportów umożliwiających wyjazdy poza granice Królestwa Polskiego. Poza tym w okresie popowstaniowym nastąpiło ogóle zubożenie kraju przez co kuracjuszy w mniejszym stopniu było stać było na wyjazdy zagraniczne, por. W. Ściborski, Poglad na ruch i postęp w zdrojowiskach krajowych podczas pory zdrojowej roku 1865 osnuty na sprawozdaniach ze zdrojowisk nadesłanych, „Przegląd Lekarski” 1866, nr 21, s. 166.

${ }^{49}$ Por. „Gazeta Lekarska” 1875, nr 1, s. 16.

${ }^{50}$ M. Raczyński, $d z$. cyt., s. 361.

${ }^{51}$ Tamże.

${ }^{52}$ Tamże.

${ }^{53}$ Całkowity koszt remontu wyniósł 1.000 rubli, tamże, s. 267, 361.

${ }^{54}$ Tamże.

${ }^{55}$ Tamże, s. 267.
} 
niekorzystnych warunków umów, jakie stawiał Zarząd prowincjonalnym teatrom chcącym bawić publiczność podczas sezonu ${ }^{56}$. Tym bardziej, że zmagały się one ze złą sytuacją finansową wynikającą z małego zainteresowania i niskiej frekwencji widzów podczas przedstawień. Zwolnienie $\mathrm{z}$ opłat za wynajem sali mogło pomóc artystom w ich utrzymaniu ${ }^{57}$.

Kolejne niewielkie remonty i modernizacje przeprowadzono w latach $1878 / 79^{58}$ oraz w 1882 r. Poszerzono wówczas istniejące wejście do obiektu oraz zrobiono drugie - boczne ${ }^{59}$. Urządzony w stajni teatr działał do końca lat 80 . XIX w. Wobec rosnących z roku na rok potrzeb uzdrowiska i wymagań gości, domagających się standardów, jakie były im znane z wizyt w kurortach zagranicznych, konieczne stało się podjęcie działań nad budową większego i bardziej spektakularnego obiektu. Tym bardziej, że wybudowany na początku lat siedemdziesiątych wał przeciwpowodziowy zabezpieczył uzdrowisko, a także umożliwił planowanie i realizację większych inwestycji, bez obawy zniszczeń.

Pierwsze propozycje wzniesienia nowego samodzielnego gmachu teatru pojawiły się już z początkiem lat 80 . XIX w. Z jedną z nich wystąpił Jan Holc, który chciał pobudować obiekt na dzierżawionej przez siebie ziemi (w pobliżu istniejącego dziś kościoła). Komitet jednak nie wydał pozwolenia na budowę, ponieważ nie był w stanie dofinansować inwestycji ${ }^{60}$. Podobnie stało się z kolejnymi dwoma projektami przedłożonymi przez Grzegorza Lanckorońskiego i Juliana Grabowskiego ${ }^{61}$.

Planów wzniesienia samodzielnego gmachu podjął się w końcu sam Zarząd uzdrowiska. Już w 1882 r. wyznaczono pod przyszły gmach teatralny teren pomiędzy stacją kolejową a hotelem Müllera, na którym dotychczas mieściło się targowisko. Rozpoczęto prace powodujące jego oczyszczenie i wyrównanie. Opracowany został plan wraz z warunkami budowy nowego gmachu przez inżyniera i budowniczego Juliana Majewskiego ${ }^{62}$. Zakładano, iż miałby to być obiekt drewniany na podmurowaniu, mogący pomieścić łącznie 420 widzów, zaś koszt jego budowy nie miał przekraczać 24000 rubli $^{63}$. Wykonanie projektu zlecono

\footnotetext{
${ }^{56}$ M.N.P., Ciechocinek, „Kłosy” 1871, nr 326, s. 195.

${ }^{57}$ Tamże.

${ }^{58}$ Koszt remontu wyniósł: 837,42 rubli. Ponadto dyrektor teatru został zobowiązany do wieczornego oświetlania obiektu na zewnątrz, por. M. Raczyński, dz. cyt., s. 273.

${ }^{59}$ Tamże, s. 361.

${ }^{60}$ Tamże, s. 275, 361. W tym czasie prowadzone były w uzdrowisku inne ważne prace budowlane - wznoszono kościół (1884) i galerię spacerową - kurhaus (1880-1881).

${ }^{61}$ Tamże, s. 361. Niezależne propozycje budowy teatru letniego wpłynęły w $1881 \mathrm{r}$.; po upływie 15 lat teatr miał przejść na własność zakładu.

${ }^{62}$ Teatr $w$ Ciechocinku, „Echo Muzyczne, Teatralne i Artystyczne” 1891, nr 406, s. 362. Julian Majewski był członkiem Komitetu, ponadto pełnił on funkcję ówczesnego kierownika prac technicznych w Ciechocinku.

${ }^{63}$ Tamże.
} 
dwóm warszawskim architektom - Edwardowi Cichockie$\mathrm{mu}^{64} \mathrm{i}$ Józefowi Hussowi. Plany tychże architektów nie spotkały się jednak z aprobatą Komitetu, gdyz - jak thumaczono - nie spełniały wymogów bezpieczeństwa przeciwpożarowego. Komitet zdecydował się na zwiększenie środków na ten cel z zamiarem wzniesienia obiektu murowanego $0^{65}$.

Nowy projekt - autorstwa Karola Kozłowskiego ${ }^{66}$ (ryc. 5) wyłoniono w konkursie ogłoszonym w 1884 r. przez Towarzystwo Sztuk Pięknych

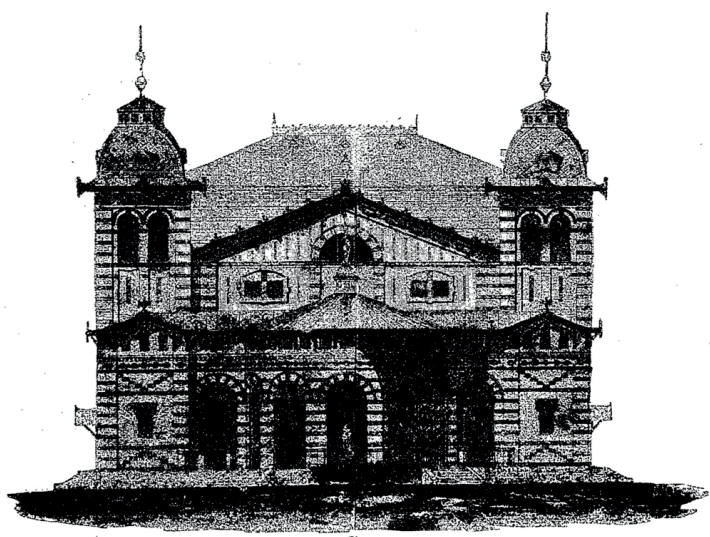

Proj ekt konkurıcwy teairu w Ciechocinku K. Kozłowskiego.

Ryc. 5. Projekt konkursowy teatru w Ciechocinku K. Kozłowskiego; Teatr w Ciechocinku, „Echo Muzyczne, Teatralne i Artystyczne" 1891, nr 406, s. 363 w Królestwie Polskim ${ }^{67}$. Projekt oceniano bardzo pozytywnie:

Całość [obiektu] udatnie zgrupowana, wyróżniająca się charakterem budowli, przeznaczonej na przedstawienia sceniczne, a zarazem noszącą na sobie cechy budowli mającej być wzniesioną w osadzie, gdzie ruch i życie objawiają się tylko w porze letniej ${ }^{68}$.

Elewacje zewnętrzne z nieotynkowanej cegły miały urozmaicać drewniane gzymsy, harmonizujące $\mathrm{z}$,zielenią trawników i drzew stanowiących tło budowli w naturze" ${ }^{69}$. Pozytywnie oceniano także projektowane wnętrze: „urządzenie i ozdobienie sali widzów, skromne, odpowiada przeznaczeniu budowli" Umieszczenie w obrębie sceny okien miało służyć jej dodatkowemu doświetleniu i umożliwić występy także w ciągu dnia bez konieczności używania sztucznego światła ${ }^{71}$.

${ }^{64}$ Edward Cichocki zaprojektował także kościół pw. św. Piotra i Pawła oraz drugą galerię spacerową, ,kurhaus" w Ciechocinku.

${ }^{65}$ Tamże.

${ }^{66}$ Tamże, s. 362-363.

${ }^{67}$ Według podanych wytycznych koszt miał nie przekroczyć 35000 rubli, Teatr w Ciechocinku..., s. 363; inne źródła podają kwotę: 40000 rubli - Z. Kiślański, Projekt teatru dla zakładu leczniczego Ciechocinku bud. K. Kozłowskiego, odznaczony 1-a nagroda konkursowa, „Przegląd Techniczny” 1884, t. 19, s. 140.

\footnotetext{
${ }^{68}$ Tamże.

${ }^{69}$ Tamże.

${ }^{70}$ Tamże.

${ }^{71}$ Tamże.
} 




Ryc. 6. Plan sceny $i$ widowni, oraz rozklad miejsc w obecnym teatrze w Ciechocinku, Teatr w Ciechocinku, „Echo Muzyczne, Teatralne i Artystyczne” 1891, nr 406, s. 362

Przedłożony w lutym 1885 r. przez Komitet Główny projekt Kozłowskiego wraz z kosztorysem ${ }^{72}$ został wstępnie zatwierdzony przez ówczesnego Generalnego Gubernatora, lecz warunkiem miało być ogłoszenie przetargu na wykonanie przyszłych prac. Licytacja jednak spełzła na niczym, gdyż brakowało zgłoszeń chętnych inwestorów, z kolei Komitet nie mógł przeznaczyć więcej środków niż te, które miał na ten cel zarezerwowane ${ }^{73}$. Sytuację utrudniała dodatkowo niejasna sytuacja własnościowa spowodowana planem sprzedaży lub wydzierżawienia całego zakładu ${ }^{74}$.

Poszukiwania inwestora trwały przez następnych kilka lat. Jeszcze w $1888 \mathrm{r}$. przedsiębiorcy upatrywano $\mathrm{w}$ potencjalnym dzierżawcy zdrojowiska, który miał wznieść obiekt i oddać go do użytku najpóźniej w dwa lata po podpisaniu umowy dzierżawy ${ }^{75}$. Ostatecznie Komitet zdecydował się połączyć istniejące już projekty przekształcając je tak, aby nowy gmach spełniał wymogi komfortu i bezpieczeństwa przy jednoczesnym uwzględnieniu skromnego budżetu ${ }^{76}$ (ryc. 6, 7).

Murowana scena wraz z garderobami miała powstać w oparciu o projekt zaproponowany przez Kozłowskiego, zmniejszono jedynie jej wysokość i uproszczono

${ }^{72}$ Planowany koszt budowy wynosił 24 893,11 rubli, koszt wyposażenia - 5100 rubli, nadzór techniczny - 1199,72 rubli, M. Raczyński, dz. cyt., s. 362.

${ }^{73}$ Teatr w Ciechocinku..., s. 363.

${ }^{74}$ M. Raczyński, dz. cyt., s. 362.

75 Tamże, s. 286. Planowany teatr objęty umową dzierżawy uzdrowiska miał być murowany, na 250 osób, a jego orientacyjny koszt miał wynieść 25000 rubli., tamże.

${ }^{76}$ Teatr w Ciechocinku..., s. 363; Teatr w Ciechocinku, „Echo Muzyczne, Teatralne i Artystyczne” 1891, nr 403, s. 327. 
mechanizmy sceniczne. Jednocześnie, aby obniżyć ogólny koszt budowy, zdecydowano się na wzniesienie widowni wraz z otaczającymi ją galeriami z drewna, z „możliwie największą ilością" "77 drzwi - tak aby w przypadku pożaru możliwa był szybka ewakuacja widzów. Za wzór posłużył pierwotny projekt zaakceptowany przez Komitet. Plan konstrukcyjny wraz z nowym kosztorysem został opracowany przez Adolfa Schimmelpfenniga, który jednocześnie objął nadzór techniczny nad pracami. Budowę Teatru Letniego rozpoczęto w $1890 \mathrm{r}^{78}$, na wyznaczonym i przygotowanym już wcześniej placu. Całkowity koszt inwestycji wyniósł ostatecznie 19000 rubli $^{79}$, czyli znacznie mniej niż zakładały pierwotne plany zakładu.

Zachowany do dnia dzisiejszego teatr wzniesiono w modnym wówczas w uzdrowiskach stylu szwajcarskim. Mógł on pomieścić łącznie 315 widzów ${ }^{80}$. Drewniana widownia ${ }^{81}$ otoczona została z zewnątrz szerokim podcieniem. Najprawdopodobniej ze względów oszczędnościowych zdecydowano się na wykonanie pozbawionej dekoracji otwartej więźby dachowej ${ }^{82}$.

Widownia mieściła na parterze 15 rzędów wygodnych foteli, pochodzących z dawnej widowni Teatru Wielkiego w Warszawie ${ }^{83}$, oraz 6 lóż. Od frontu, po obu stronach głównego wejścia, urządzono kasę, szatnię oraz bufet. Po obu stronach sceny ${ }^{84}$ urządzono magazyny, zaś za nią powstało łącznie 8 pomieszczeń garderobianych rozmieszczonych na 2 kondygnacjach ${ }^{85}$. Dla zwiększenia bezpieczeństwa przeciwpożarowego scenę wyposażono $\mathrm{w}$ dodatkowy hydrant (istniał jeszcze hydrant zewnętrzny) ${ }^{86}$. Teatr robił dobre wrażenie. Jest to „obszerny i ładny budynek z salą drewnianą należycie wentylowaną, mogącą pomieścić 300 widzów, i obszerna murowaną sceną".

${ }^{77}$ Teatr w Ciechocinku ..., 1891, nr 406, s. 363.

${ }^{78}$ Nadzór budowlany objął Jan Mianowski, prace murarskie powierzono Gustawowi Kuzelowi, zaś ciesielskie - Henrykowi Elgiertowi, M. Raczyński, dz. cyt., s. 287, 362. Wykonanie mechanizmów scenicznych konsultowano z warszawskim mechanikiem teatralnym - Jasińskim, tamże, s. 288. Kurtynę, jak również teatralne dekoracje, zostały wykonane przez cenionego wówczas malarza i dekoratora teatrów warszawskich Adama Malinowskiego, E. Sokal, Ciechocinek w obecnej chwili, „Wędrowiec” 1896, nr 31, s. 79.

${ }^{79}$ Teatr w Ciechocinku ..., 1891, nr 406, s. 363.

${ }^{80}$ Tamże, s. 363; Teatr w Ciechocinku..., 1891, nr 403, s. 327.

${ }^{81}$ Wymiary widowni: 49 x 51 stóp, wys. 31 stóp (ok. 15 x 15,5 m, wys. 9,5 m). Przy scenie znajdowała się część na pomieszczenie orkiestry o wymiarach 28 × 8 stóp (ok. 8,5 x 2,5 m), Teatr w Ciechocinku..., 1891, nr 406, s. 363.

${ }^{82}$ G. Ruszczyk, Rozwój drewnianej architektury uzdrowiskowej w XIX i na początku XX wieku na przyktadzie Ciechocinka, [w:] Architektura kurortowa. Materiaty z ogólnopolskiej konferencji ,Architektura Kurortowa", Połczyn Zdrój 24 - 25 kwietnia 2009, Szczecin 2009, s. 150.

${ }^{83}$ E. Sokal, Ciechocinek...., s. 79.

${ }^{84}$ Wymiary sceny: 52 x 38 stóp, wysokość 21 stóp ( 16 x 11,5, wys. 6,5 m), Teatr w Ciechocinku ..., 1891, nr 406, s. 363.

${ }^{85}$ Tamże.

${ }^{86}$ E. Sokal, Ciechocinek..., s. 79. 
- pisano na łamach ówczesnego „Tygodnika Ilustrowanego" ${ }^{87}$. Przedstawia się on „efektownie”, a pod względem budowy „w zakresie skromnego budżetu, [...] uczyniono wszystko, co dla wygody i bezpieczeństwa uczynić było można"s8.

Otwarcie teatru nastąpiło na przełomie czerwca i lipca 1891 r. Pierwszą sztuką odegraną na nowych deskach był „Wicek i Wacek” na podstawie tekstu Zygmunta Przybylskiego wystawiany przez trupę Stanisława Sarnowskiego (5 lipca 1891 ${ }^{89}$. Zainteresowanie pierwszymi widowiskami było ogromne. Salę wypełnili po brzegi nie tylko goście uzdrowiska, ale i okoliczni mieszkańcy ${ }^{90}$.

Pierwsze zespoły teatralne płaciły za wynajem budynku, a dodatkowo musiały wnieść również kaucję ${ }^{91}$ Z czasem zarząd udostępniał obiekt nie pobierając opłaty, zaś przyjezdni artyści zobowiązani byli płacić jedynie za oświetlenie ${ }^{92}$. Zdarzało się też, że w zamian za bezpłatne udostępnienie lokalu artyści zobowiązywali się wykonać określone prace renowacyjne przy obiekcie ${ }^{93}$.

Na początku XX w. przeprowadzono zewnętrzny remont teatru oraz zmodernizowano jego wnętrze. Wykonana wówczas została zapadnia pod sceną, a na widowni dodano 2 loże i balkon po przeciwległej stronie sceny ${ }^{94}$. Ponadto ciechociński teatr wzbogacił się o dużą ilość starych dekoracji ofiarowanych mu przez warszawskie teatry rządowe ${ }^{95}$.

Należałoby również wspomnieć o frekwencji podczas teatralnych przedstawień. Z pewnością oczekiwania oraz nadzieje pokładane względem nowego gmachu były bardzo duże. Teatr Letni w Ciechocinku miał stać się swoistą wizytówką uzdrowiska przyciągającą do niego nowych gości i przynoszącą realne zyski. Wysoka frekwencja na pierwszych spektaklach wróżyła pomyślną przyszłość teatru, co jednak, jak pokazała rzeczywistość, nie trwało długo. Liczba widzów malała, a występujące w uzdrowisku kolejne grupy teatralne w dalszym ciągu zmagały się ze sporymi trudnościami finansowymi. Powodów takiego stanu rzeczy zapewne było kilka. Paradoksalnie, do pójścia do teatru wypoczywających w uzdrowisku gości nie zachęcała ani dobra, ani zła pogoda. Kiedy aura była pomyślna kuracjusze udawali się na spacer. Z kolei deszczowe popołudnia spędzali z reguły w domach. Niesprzyjającym był również fakt, iż Ciechocinek nie

${ }^{87}$ W. Szumlański, 50-lecie Ciechocinka. Kartka z dziejów naszych zakładów kapielowych z 11 fotografiami, „Tygodnik Ilustrowany” 1897, nr 26, s. 514.

${ }^{88}$ Teatr w Ciechocinku..., 1891, nr 403, s. 327.

${ }^{89}$ Teatr w Ciechocinku..., 1891, nr 406, s. 363.

${ }^{90}$ Tamże.

${ }^{91}$ Dzierżawa początkowo wynosiła 270 rubli, zwiększono ją w 1898 r. do 400 rubli; kaucja wynosiła 100 rubli, M. Raczyński, dz. cyt., s. 362.

${ }^{92}$ Wysokość opłaty wynosiła 300 rubli, tamże.

${ }^{93}$ Andrzej Lelewicz w 1909 r. w zamian za bezpłatne udostępnienie obiektu zobowiązał się odmalować budynek, tamże.

${ }^{94}$ Zewnętrzny remont obiektu (1901 r.) kosztował 4400 rubli, wykonanie zapadni - 600 rubli, koszt wykonania lóż i balkonu (1902 r.) - 110 rubli, tamże.

${ }^{95}$ Tamże. 


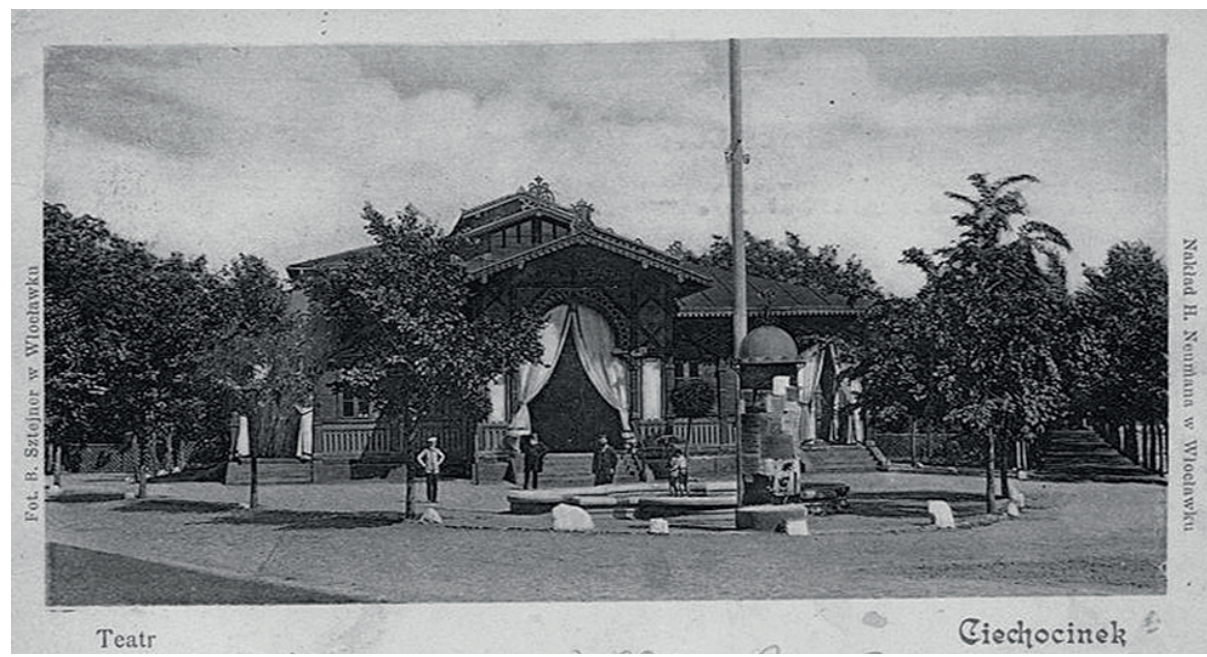

Ryc. 7. Teatr Letni w Ciechocinku, pocz. XX w., kartka pocztowa nakład H. Neuman, Włocławek, www.ciechocinek.fotopolska.eu, 29.11.2014

był oświetlony nocą, a ponieważ przedstawienia z reguły kończyły się po zmroku - trudno i nieprzyjemnie było wracać w ciemnościach do wynajmowanych kwater ${ }^{96}$. Problemem było także podtrzymanie zainteresowania gości proponowanym repertuarem. Ówczesna kuracja w uzdrowisku trwała bowiem znacznie dłużej, niż jest to dziś praktykowane. Goście zjeżdżali do kurortu na miesiąc, dwa, a niekiedy i na cały sezon, który z reguły trwał od maja do przełomu września i października. Trudno było zatem występującej w tym samym składzie grupie teatralnej podtrzymać zainteresowanie niemal niezmieniającej się publiczności. Inny powód


sezon w uzdrowisku składały się 3 okresy $^{98}$. W okresie pierwszym i trzecim do uzdrowiska zjeżdżała z reguły publiczność uboższa, mająca ograniczony budżet. Po opłaceniu podstawowych kosztów, jakimi były zabiegi lecznicze, mieszkanie i utrzymanie, niewielka ilość pozostałych im pieniędzy doprowadzała do konieczności wyboru pomiędzy oferowanymi rozrywkami. I tak, jak pokazywała rzeczywistość, kuracjusze chętniej decydowali się na pójście na koncert, niż na teatralne przedstawienie. Taka sytuacja nie była jednak rzeczą nową i utrzymywała się w uzdrowisku już przez wiele lat ${ }^{99}$. W drugim - środkowym okresie, trwającym od

\footnotetext{
${ }^{96}$ Cz. Jankowski, Z wrażeń letniej wycieczki. Ciechocinek, „Kurier Warszawski” 1891, nr 239, s. 3.

${ }^{97}$ Teatr w Ciechocinku..., 1891, nr 403, s. 327.

${ }^{98}$ Okres pierwszy trwał od początku maja (początek sezonu) do połowy czerwca, drugi - od połowy czerwca do połowy sierpnia, trzeci - od połowy sierpnia do końca września (zakończenie sezonu).

${ }^{99}$ Już w latach pięćdziesiątych XIX w. problem ten został dostrzeżony przez sam Zarząd uzdrowiska, który domagał się kontrolowania, a wręcz ograniczenia ilości dawanych w ośrodku koncertów. Zaproponowano nawet, aby pewna suma pieniędzy od każdego koncertu była przekazywana na utrzymanie artystów dramatycznych, APW, KZZWM 10, k. 63-64.
} 
połowy czerwca do połowy sierpnia, w uzdrowisku gościli zamożniejsi kuracjusze, których obecność przyczyniała się do znacznego podnoszenia cen mieszkań i żywności przez zarząd uzdrowiska. Taki stan rzeczy powodował, że i sama grupa teatralna musiała podnieść znacznie koszty swoich spektakli, co było nieopłacalne przy tak niskiej sprzedaży biletów. Problem stanowiły również wysokie wymagania owej publiczności co do jakości artystycznych przedstawień. Przybywających wówczas do kurortu kuracjuszom z dużych miast (głównie Warszawy) nie satysfakcjonowały występy „średniej trupy, której wydowiska nie wypełniają widowni po brzegi" ${ }^{100}$. Korespondent wspomnianego czasopisma, „Echa Muzycznego” sugeruje, iż o powodzenie ciechocińskiego gmachu nie należałoby się martwić, gdyby uznać go za „filię teatrów rządowych warszawskich”, w którym gościnnie - dwa lub trzy razy w tygodniu występowaliby aktorzy Teatru Małego lub Teatru Rozmaitości ${ }^{101}$. To jednak nigdy nie miało miejsca. Teatr stopniowo zaczął przynosić straty, które próbowano pokrywać urządzanymi tam koncertami, na które zapraszano znanych artystów ${ }^{102}$.

Za powód niskiej frekwencji, która utrzymywała się także w kolejnych latach, wymieniano również odbywające się w tym samym czasie, co widowiska teatralne koncerty symfoniczne - dlatego teatr ,świeci z tego powodu pustkami” - tłumaczono ${ }^{103}$. Jeszcze na początku XX w. na łamach czasopism sugerowano, iż być może sprowadzenie do Ciechocinka bardziej znanych artystów dramatycznych mogłoby uratować sytuację i ożywić uzdrowiskowe życie teatralne ${ }^{104}$.

Reasumując - po prześledzeniu historii ciechocińskiego teatru wysnuć można wniosek, iż Zarząd kurortu w niewielkim stopniu finansował ten rodzaj rozrywki, co wynikało z nie dość dobrej sytuacji ekonomicznej całego zdroju. Inwestycje zazwyczaj ograniczały się do niewielkich remontów, drobnych udogodnień i napraw najbardziej niezbędnych. Teatr traktowany był raczej drugoplanowo, stał w cieniu innych potrzeb uzdrowiska. Dwa pierwsze obiekty teatralne w Ciechocinku, były bardzo skromne. Jednocześnie ze źródeł wynika, że przez znaczną większość czasu ich istnienia, przedstawiały się raczej jako obiekty popadające $\mathrm{w}$ ruinę. $\mathrm{O}$ ich złym stanie technicznym świadczą nie tylko prasowe komentarze, które można by uznać za dość subiektywne, ale i informacje pochodzące z samych akt archiwalnych Komitetu. Do chęci przeznaczenia większych środków finansowych na teatr nie mobilizowała też zapewne niska frekwencja widzów. Kolejne obiekty wznoszono przy zachowaniu maksimum oszczędności upraszczając projekty, budując je z tańszych, niż pierwotnie planowano materiałów, a samo wyposażenie pozyskiwano z innych instytucji.

\footnotetext{
${ }^{100}$ Teatr $w$ Ciechocinku..., 1891, nr 403, s. 327.

${ }^{101}$ Tamże.

${ }^{102}$ Koncerty te niestety w rezultacie doprowadziły do zwiększenia teatralnego deficytu, M. Raczyński, dz. cyt., s. 296.

${ }^{103}$ „Echo Ciechocińskie”. Jednodniówka, Ciechocinek 1910, s. 5

${ }^{104}$ „Głos Ciechociński”. Jednodniówka, Ciechocinek 1910, s. 2.
} 
Pomimo tak wielu przeciwności, Zarząd nie mógł zrezygnować z istnienia uzdrowiskowego teatru. Bowiem nawet najskromniejszy podnosił prestiż ośrodka. W XIX-wiecznych przewodnikach każdorazowo wymieniany jest jako jedna $\mathrm{z}$ podstawowych oferowanych rozrywek. Poza tym jego istnienia domagali się także sami kuracjusze. Zarząd zatem, aby utrzymać go i pomóc w jego funkcjonowaniu, m. in. wspierał artystów dramatycznych zwalniając ich z opłat za wynajem sali, czy też podejmując próby ograniczenia organizowanych w uzdrowisku koncertów.

Jak pokazuje historia, pomimo szczerych chęci nigdy nie tylko sam teatr, ale i całe uzdrowisko Ciechocinek, uznawane od drugiej połowy XIX w. za największe i najbardziej popularne uzdrowisko na terenie Królestwa Polskiego, nie miało szans rozwoju na tym samym poziomie co uzdrowiska zachodnie wobec czego nigdy nie mogło im w pełni dorównać.

Agnieszka Kania

\section{OBJECTS OF CULTURAL LIFE IN CIECHOCINEK IN THE NINETEENTH CENTURY. THEATRE}

In the $19^{\text {th }}$ century seasonal trips to health resorts were very common. People would venture there not only for health reasons but mostly to relax and have fun. Development of western health resorts was very rapid and the service-providing objects were built on the great scale there. Many of them were located also on the ex-polish grounds, due to Partitions. One of the largest and mostly visited resorts was located in Ciechocinek. Owners were forced to successively develop new balneological and cultural offer to raise its competitiveness and attractiveness. One of the strongest points of local entertainment was the theatre.

The paper discusses the history of consecutive theatre stages, located in Ciechocinek. It also highlights many challenges that the pioneers had to overcome. Often theatre owners confronted by low funding were forced to delay new investment by years while modifying initial plans to make them far less complicates. The very first theatres in Ciechocinek were very modest. They were initially housed in sheds or adapted barns. The first purpose built theatre - so called Summer Theatre - was built in the $80^{\mathrm{s}} / 90^{\mathrm{s}}$ of the $19^{\text {th }}$ century. Almost 50 years after the foundation of the resort. The article also describes the complicated situation of theatre crews and spectators attendance during plays. 